\title{
An International Committee on the History of Sciences.
}

THERE was recently held in Paris the first meeting of the Comité International d'Histoire des Sciences, which owes its existence to the International Congress of Historians. At the meeting of that body last year at Oslo, the first steps were taken towards the formation of the new Comité. Most benevolent and practical interest in the Comité International has been evinced by the permanent office of the parent body, and especially by its distinguished secretary, M. l'Héritier. It is consonant with our experience of other intellectual movements that the stimulus towards studies on the history of science has come not from governments nor even from universities, but from voluntary associations of individual workers. As the heroic figure of the movement for the study of the history of science, we may cite Dr. George Sarton, a Belgian who is now domiciled in the United States. His self-sacrificing industry was interrupted but not deflected by the European upheaval. He has now the satisfaction of watching the growth of the History of Science Society, which has honoured itself by contributing some part of the cost of Sarton's remarkable journal Isis. The History of Science Society has its centre in Washington. It numbers many Europeans among its members, and welcomes all who take interest in the history of science.

The newly-formed Comité International d'Histoire des Sciences has its seat in Paris. The Comité itself will consist exclusively of persons actively engaged in investigating problems within the field of the history of science and technology. It will comprise 30 membres effectifs and 50 membres correspondants. They will meet annually in Paris, while every three years they will hold larger international congresses. The Comité is of course in active co-operation with the larger History of Science Society, to which all of its members belong, and there is no sort of rivalry between the two bodies.

The first president of the Comité International d'Histoire des Sciences is the very distinguished Italian mathematician and writer on the history of mathematics, Prof. Gino Loria of Genoa. The honorary secretary is Prof. Aldo Mieli, distinguished both for his own writings on the history of science and for the journal Archeion edited and published by him. The success of the recent Paris meeting of the Comité was mainly due to the admirable organisation of Prof. Mieli.

The French Government has allotted to the Comite a beautiful home in the Hôtel Nevers, a seventeenth century house which formerly belonged to Mme. de Lambert and afterwards held the first nucleus of the Bibliothèque Nationale. Here Prof. Mieli is organising a Centre International d'Histoire des Sciences, in which he will be assisted by Mme. Hélène Metzger, author of important contributions to the history of chemistry and physics. Madame Metzger will act as archivist and librarian.

In the Hotel Nevers the members of the Comité recently assembled, the constitution of the Comite was agreed upon, and a number of most interesting papers were read. Among them were contributions both by the president and by Prof. Ruska of Berlin on the importance of Arabic manuscripts for the study of the history of mathematics ; by Prof. Thorndike of Columbia University, president of the History of Science Society, on a treatise on surgery ascribed both to John Braccia and to Peter of Tossignano ; by Prof. Mieli on Spallanzani and his relationship to Redi and to Pasteur; by Prof. Dingler of Munich on Nicholas of Oresmes ; by Prof. Darmstaedter of Munich on his remarkable experiments to elucidate the formation of copper and silver alloys described in ancient treatises of alchemy ; by Prof. Sigerist of Leipzig on the organisation of medical historical research; and by Dr. Feldhaus of Berlin on his Institute for the History of Technology. Prof. Vetter of Prague described the holograph manuscript of the "De Revolutionibus Orbium Celestium " of Copernicus, now at Prague. He discussed the interesting divergences between the manuseript and the first printed edition, and it was agreed that the manuscript should if possible be published in facsimile as an important historical document.

One session, attended by many distinguished visitors, was devoted to a commemoration of the work of the late Paul Tannery, who not only himself made important contributions to the history of science, but also, so early as 1903, at the International Congress of Historians in Rome, foreshadowed the creation of a permanent international body for the study of the history of science.

Paris opened its hospitable doors to the Comité. A dinner was given by the parent Comité International des Sciences Historiques, and a reception by the Institut International de Coopération Intellectuelle. The latter was the occasion of an eloquent address by the assistant director of the Institut, Prof. Alfred Zimmern, who expressed the hope that, through the history of science and cognate synthetic movements, it might be possible for the mind of the savant to exercise its legitimate influence in the international comity of nations.

Dr. Charles Singer was elected president of the Comité International d'Histoire des Sciences for the next two years, and it was decided to hold an international congress in London in 1931.

\section{Meteorology in British East Africa.}

$\mathrm{T}^{\mathrm{H}}$

E first Memoir of what is to be known as the British East African Meteorological Service, from the pen of its director, Mr. A. Walter, formerly director of the Royal Alfred Observatory, Mauritius, has recently been received. This memoir describes the circumstances leading up to the inauguration of a joint meteorological service for British East African territories. The money for the undertaking is to be contributed by the Governments of Egypt, the Sudan and Zanzibar, and those of the East African colonies Uganda, Kenya, Tanganyika, and Northern Rhodesia; the Egyptian Government is intimately concerned with the acquisition of meteorological information from the East African uplands, the rainfall of which controls the Nile flow, and not inappropriately makes the largest financial contribution. For many years records of rainfall and temperature have been collected by the agricultural departments of Kenya, Uganda, and Zanzibar, and Tanganyika possessed a fully organised meteorological service when under German rule.

The new service begins with funds amounting to nearly $£ 7000$ a year and is able to undertake a comparatively ambitious programme involving the organisation of five 'first order' stations, where the work will include electrical and magnetic observations, measurements of solar radiation, and the exploration of upper wind currents by means of pilot balloons. In addition, there will be about forty "second order" telegraphic reporting stations, at which observations 
of atmospheric pressure, wind direction and velocity, rainfall and cloud, will be made twice a day. The stations will be important in connexion with weather forecasting for the air services, and it is hoped that they will assist the forest advisers of Government in the problem of the progressive desiccation of Africa.

The fact that the funds necessary for the launching of such a large meteorological service in a few years were forthcoming, taken in conjunction with the slow growth of European services in the latter half of last century, shows the extraordinary increase of recognition of the value of applied science that has taken place within the last ten or fifteen years.

\section{University and Educational Intelligence.}

Cambridge.--At Emmanuel College the studentship offered to a student of another university intending to begin research in Cambridge in October 1929 has been awarded to Mr. J. K. L. MacDonald, of McGill University, Montreal, for research in physics. The following awards have been made from the Research Fund to members of the College: Student. ships of $£ 150$ each for two years to N. W. Pirie (biochemistry) and S. Clay (botany); grants to J. G. A. Griffiths (physical chemistry) and E. W. Pickford (psychology).

Mr. E. T. C. Spooner has been elected to a research fellowship at Clare College. Mr. Spooner was placed in the first class of the Natural Sciences Tripos, Part II. (pathology) in 1925 and was elected to a Commonwealth Fellowship tenable at Harvard in May 1929.

DURING the next few months about a hundred officers will be required by the Royal Air Force for flying duties under the short service commission scheme. Applications are accordingly invited from well-educated candidates of good physique who are between the ages of eighteen and twenty-five years. During their period of service, short service officers have opportunites for preparing themselves for civil life; a competitive examination is also held annually, and from this a limited number of short service officers are appointed to specialist courses in engineering, wireless telegraphy, armament, etc., with the view of obtaining permanent commissions in the Royal Air Force. Particulars can be obtained from the Secretary, Air Ministry, Kingsway, London, W.C.2.

From the Universities of Cambridge and Leeds we have received pamphlets containing abstracts of theses approved for research degrees during 1927-28. The Cambridge dissertations are classified as follows : chemistry 12 ; physics 10 ; biochemistry 7 ; botany 3 ; geology 3 ; zoology 2 ; mathematies 2 ; agriculture 2 ; engineering 1 ; metallurgy 1 ; experimental psychology 1; pathology 1; physiology 1; English, history, languages, and law, 9. Of the fifty-six authors (of whom six were women), thirty-one had come to Cambridge from other universities, namely, from other universities in Great Britain 12, from North America 7, Australia 4, South Africa 3, India 2, Ireland 1, South America 1, Russia 1. The Leeds pamphlet, which includes also lists of other researches and publications by members of the staff and graduate students, gives abstracts of theses as follows: in chemistry 8 (including 6 in colour chemistry), botany 5 , mathematics 2 , gas-engineering 1. Though somewhat belated, the publication of these abstracts, running in most cases to five or six hundred words, should prove useful to other research workers.

No. 3120, VoL. 124]
THE International Federation of University Women has issued a bulletin of 104 pages containing a report. of its council meeting held in Madrid last September, including reports of 28 national associations and a list of international club-houses and hotels. Founded ten years ago, it has steadily extended its membership and it now embraces almost every country in Europe, the United States of America, Canada, Mexico, South Africa, Australia, New Zealand, and India. Furthermore, ground is being broken in South America. Chile and Ecuador were represented at the meeting by Mlle. Mistral, technical adviser for Spanish America at the International Institute for Intellectual Co-operation, and the adhesion of associations of university women in most of the South American republics in the near future is confidently anticipated. The function of the Federation in relation to the university women of all these countries is, declared its president, Dr. Ellen Gleditsch, of Oslo, in a public address at Madrid, "to act as a catalyst in the chemistry of international relations". One of its chief enterprises is the establishment of international fellowships to enable scientifically trained women to study in countries other than their own. As yet the endowment fund does not permit the award of more than one fellowship annually, but there are others available within the organisation, such as the two recently offered by a member of the Australian federation, one offered by the American Association, and the residential scholarships offered by the Paris Club and by Crosby Hall in London. A campaign for raising a capital sum of a million dollars for this purpose is in progress. The Federation is financed mainly by contributions from the United States.

From the Kent Education Committee we have received a copy of " Education in Kent, 1923-1928", by E. Salter Davies, the County Director of Education. This volume, comprising a report covering 180 pages and numerous tabular statements, plans of buildings, and photographs, constitutes a record (to use the author's words) of "five strenuous and difficult years of self-examination, stocktaking, and reconstruction", and contains much valuable evidence of modern tendencies in English education. Very conspicuous are the evidences of the far-reaching effects on organisation, staffing, curricula, training of teachers, and buildings of the modern emphasis on individual differences. In a chapter on the reorganisation of elementary schools the report details the steps taken and planned, in accordance with the principles set out in the Board of Education's pamphlet, "The New Prospect in Education" of 1928 (sequel to the Hadow Report of 1926) towards the provision for all adolescents (ages 1I-15) of "realistic and eminently practical forms of education which will develop the capability of the pupils to the full according to their several abilities and will equip them for their work in life". To ensure efficient classification and differentiation between pupils of different types of capacity and of different aptitudes, the committee has for some years provided facilities for obtaining training in the testing of individual capacities. In selected areas it has prescribed the use of a pupil's record card on which are recorded year by year the results of applying certain psychological tests. There has been, the report says, a very decided increase of late in the study of elementary science, particularly on the practical side. The supply of science apparatus is centralised through the Committee's Stores Department, which last year spent $£ 4672$ on it out of a total budget of $£ 103,491$. For elementary botany a microscope set is made to the committee's specification by a firm of engravers in the county. 